\title{
Evaluation of Antioxidant Compounds, Antioxidant Activities, and Mineral Composition of 13 Collected Purslane (Portulaca oleracea L.) Accessions
}

\author{
Md. Amirul Alam, ${ }^{1}$ Abdul Shukor Juraimi, ${ }^{1}$ M. Y. Rafii, ${ }^{1,2}$ Azizah Abdul Hamid, ${ }^{3}$ \\ Farzad Aslani, ${ }^{1}$ M. M. Hasan, ${ }^{1}$ Mohd Asraf Mohd Zainudin, ${ }^{3}$ and Md. Kamal Uddin ${ }^{1}$ \\ ${ }^{1}$ Department of Crop Science, Faculty of Agriculture, Universiti Putra Malaysia (UPM), 43400 Serdang, Selangor, Malaysia \\ ${ }^{2}$ Institute of Tropical Agriculture, Universiti Putra Malaysia (UPM), 43400 Serdang, Selangor, Malaysia \\ ${ }^{3}$ Faculty of Food Science and Technology, Universiti Putra Malaysia (UPM), 43400 Serdang, Selangor, Malaysia
}

Correspondence should be addressed to Md. Amirul Alam; amirul81@gmail.com

Received 3 September 2013; Revised 20 October 2013; Accepted 21 October 2013; Published 21 January 2014

Academic Editor: John B. Vincent

Copyright (c) $2014 \mathrm{Md}$. Amirul Alam et al. This is an open access article distributed under the Creative Commons Attribution License, which permits unrestricted use, distribution, and reproduction in any medium, provided the original work is properly cited.

The methanolic extracts of 13 accessions of purslane were analyzed for their total phenol content (TPC), total flavonoid contents (TFC), and total carotenoid contents (TCC) and antioxidant activity of extracts was screened using FRAP assay and DPPH radical scavenging methods. The TPC, TFC, and TCC ranged from $0.96 \pm 0.04$ to $9.12 \pm 0.29 \mathrm{mg} \mathrm{GAE} / \mathrm{g}$ DW, $0.13 \pm 0.04$ to $1.44 \pm 0.08 \mathrm{mg}$ $\mathrm{RE} / \mathrm{g} \mathrm{DW}$, and $0.52 \pm 0.06$ to $5.64 \pm 0.09 \mathrm{mg}$ ( $\beta$-carotene equivalent) $\mathrm{BCE} / \mathrm{g} \mathrm{DW}$, respectively. The DPPH scavenging $\left(\mathrm{IC}_{50}\right)$ activity varied between $2.52 \pm 0.03 \mathrm{mg} / \mathrm{mL}$ and $3.29 \pm 0.01 \mathrm{mg} / \mathrm{mL}$ and FRAP ranged from $7.39 \pm 0.08$ to $104.2 \pm 6.34 \mu \mathrm{mol} \mathrm{TE} / \mathrm{g}$ DW. Among all the measured micro- and macrominerals $\mathrm{K}$ content was the highest followed by $\mathrm{N}, \mathrm{Na}, \mathrm{Ca}, \mathrm{Mg}, \mathrm{P}, \mathrm{Fe}, \mathrm{Zn}$, and Mn. The overall findings proved that ornamental purslane was richer in antioxidant properties, whereas common purslane possesses more mineral contents than ornamental ones.

\section{Introduction}

Antioxidants are vital substances which possess the ability to protect the body from damages caused by free radicalinduced oxidative stress, whereas the micro- and macrominerals are the key components for overall body growth and development. Purslane has been ranked as the eighth most common plant in the world [1] and is listed in the World Health Organization as one of the most used medicinal plants and it has been given the term "Global Panacea" $[2,3]$. There are about 70 species of edible herbs in Malaysia, which are called by their local name "ulam" [3]. Some of these herbs are claimed to have high antioxidant properties as well as medicinal properties. Purslane is the most prominent candidates among all those herbs. The complex mixture of phytochemicals in vegetables and fruits provides overlapping or complementary effects that contribute to the protective effect of health [4]. The common purslane (Figure 1(a)) locally known as "Gelang Pasir" in Malaysia and Indonesia and ornamental purslane are mainly know as Japanese rose [3]. Purslane is an annual succulent (water content of over 90\%), glabrous, prostrate, or ascending plant, $10-70 \mathrm{~cm}$ high, very much branched from the base. Leaves are alternate, fleshy, obovate or spathulate with a cuneate base and obtuse apex, smooth and waxy on upper surface, margins are sometimes purple; sessile or indistinctly petiolate, $1-3 \mathrm{~cm}$ long, $0.5-$ $1.5 \mathrm{~cm}$ wide. Flowers are solitary or clustered axillary or terminal, surrounded by 2 glabrous bracts; 2 unequal sepals, 5 glabrous yellow petals, stamens $6-15$. Fruit are brown rounded capsule, $6-10 \mathrm{~mm}$ long, opening at top with lid. Seeds are numerous, small, $0.8 \mathrm{~mm}$ broad, reniform, and black in color [5-8], whereas ornamental purslane usually does not produce seeds but is potentially propagated by stem cuttings. Leafy vegetables are good source of vitamins and minerals. Portulaca oleracea has been reported to be the richest vegetable source of omega-3 $(\omega-3)$ fatty acids (FA) yet 


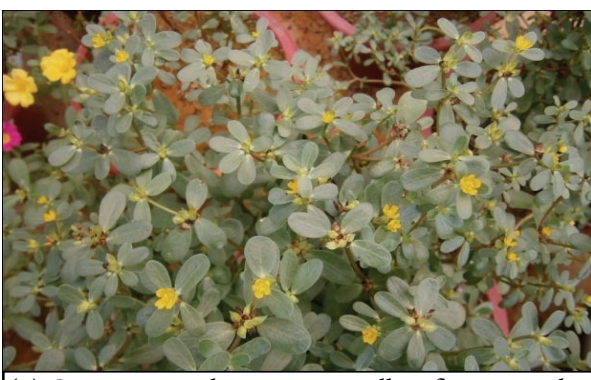

(1) Common purslane; minute yellow flower, singlelayered petals, paddle-shaped leaves, green-red stem

(a)

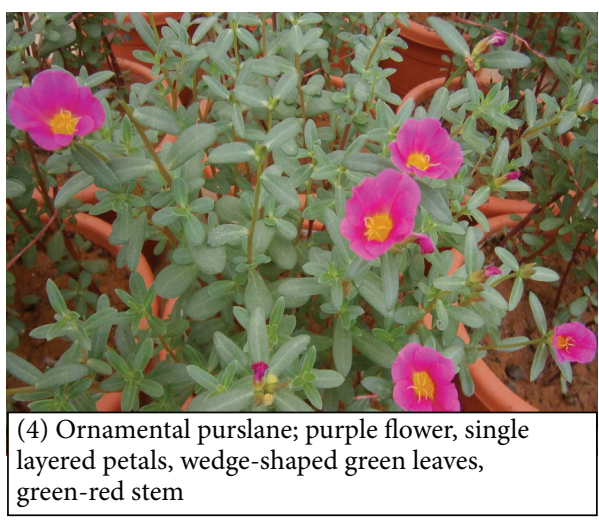

(c)

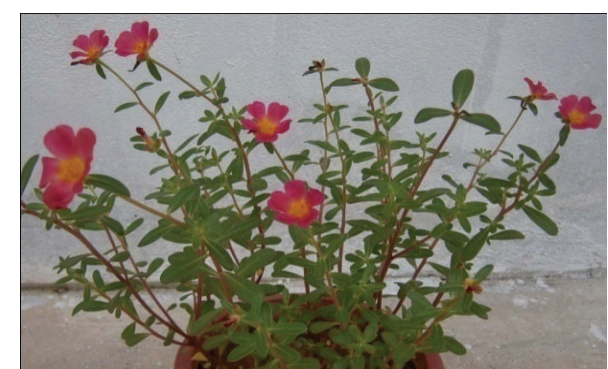

(2) Ornamental purslane; pink flower, single layered petals, wedge-shaped green leaves, red stem

(b)

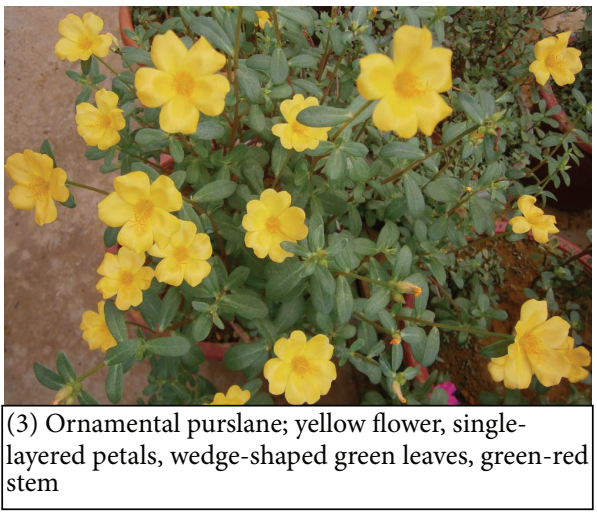

(d)

FIgURE 1: Different types of purslane with brief descriptions.

examined [9]. Subsequent reports have confirmed the high levels of $\omega$-3 fatty acids and traces of 22: $5 \omega-3$ and 22: $6 \omega-$ $3[10,11]$. Purslane also contains high levels of vitamins E, $\mathrm{C}$, and beta carotene [12]. The abundance of high levels of these essential nutrients in purslane indicates its potential for becoming a new source of nutritious food for both humans and animals. Scientifically, purslane provides a rich plant source of nutritional benefits with high antioxidant properties. It is one of the richest green plant sources of omega-3 fatty acids $[9,10]$. In areas where this "weed" is eaten, there is a low incidence of cancer and heart disease, possibly due to purslane's naturally occurring omega-3 fatty acids $[12,13]$. Purslane has long been known in Malaysia but still it is underutilized and considered as a weed. To our knowledge, no data on nutritional quality have been published regarding such many different types of collected purslane accessions. Therefore, the objective of this study was to characterize the nutritional components, antioxidant compounds, and antioxidant activities of collected purslane accessions for cultivars evaluation and to select the better cultivars in an attempt to promote their cultivation as a vegetable crop and safely use for human consumption.

\section{Materials and Methods}

2.1. Experimental Site and Soil. The experiment was conducted during May 2012 to September 2012 in a glasshouse at the Faculty of Agriculture, University Putra Malaysia $\left(3^{\circ} 00^{\prime} 21.34^{\prime \prime} \mathrm{N}, 101^{\circ} 42^{\prime} 15.06^{\prime \prime} \mathrm{E}, 37 \mathrm{~m}\right.$ elevation $)$, and Food Biotechnology and Functional Food Research Laboratory, Faculty of Food Science and Technology, UPM, Malaysia. The plastic pots $(24 \times 22 \mathrm{~cm})$ were filled with soil $(39.51 \%$ sand, $9.03 \%$ silt, and $51.35 \%$ clay) of $\mathrm{pH} 4.8$ with $2.6 \%$ organic carbon, $1.24 \mathrm{~g} \mathrm{cc}-1$ bulk density, and CEC of 7.07 me $100 \mathrm{~g}^{-1}$ soil. Soil nutrient status was $0.16 \%$ total N, $5.65 \mathrm{ppm}$ available P, 15.3 ppm available K, 3295 ppm Ca, and 321 ppm Mg. At field capacity, soil water retention was $31.18 \%$ (wet basis) and $45.31 \%$ (dry basis). The experimental soil belongs to the Serdang series.

2.2. Plant Materials and Experimental Design. Thirteen (13) samples of 10-15 days young seedlings of purslane were collected from different locations of West Peninsular Malaysia considering location and morphological variation of the plants and transplanted into the pots with prepared soils organized in a randomized complete block design with three replications. Brief descriptions of the collected samples and locations are shown in Table 1 and Figure 1.

2.3. Plants Rearing and Sample Collection. Four to five seedlings were transplanted in each pot and were surface-irrigated thrice a week (every alternate day) throughout the growing period using only tape water. Sixty day-old matured harvested purslane samples were divided into two parts of each accession: one for the analysis of antioxidant properties and the other for mineral analysis. Due to light and temperature 
TABLE 1: Brief descriptions of collected purslane accessions collected from different locations.

\begin{tabular}{|c|c|c|c|c|c|}
\hline $\begin{array}{l}\text { Acc. } \\
\text { no. }\end{array}$ & State & Locations & $\begin{array}{l}\text { Latitude } \\
\left({ }^{\circ} \mathrm{N}\right)\end{array}$ & $\begin{array}{l}\text { Longitude } \\
\left({ }^{\circ} \mathrm{E}\right)\end{array}$ & Brief descriptions of the plants \\
\hline 1 & Selangor & Tanjung Karang & $03^{\circ} 41^{\prime}$ & $101^{\circ} 19^{\prime}$ & $\begin{array}{l}\text { Yellow flower, paddle-shaped green leaf, } \\
\text { red stem. }\end{array}$ \\
\hline 2 & Selangor & Tanjung Karang & $03^{\circ} 41^{\prime}$ & $101^{\circ} 19^{\prime}$ & $\begin{array}{c}\text { Pink flower, paddle-shaped green leaf, red } \\
\text { stem. }\end{array}$ \\
\hline 3 & Penang & Seberang Perai & $05^{\circ} 54^{\prime}$ & $100^{\circ} 47^{\prime}$ & $\begin{array}{l}\text { Yellow flower, paddle-shaped, margin } \\
\text { green red leaf, red stem leaf }\end{array}$ \\
\hline 4 & Penang & Seberang Perai & $05^{\circ} 54^{\prime}$ & $100^{\circ} 47^{\prime}$ & $\begin{array}{c}\text { Pink flower, wedge-shaped green red leaf, } \\
\text { red stem }\end{array}$ \\
\hline 5 & Kedah & Nursery, Kedah & $06^{\circ} 11^{\prime}$ & $100^{\circ} 37^{\prime}$ & $\begin{array}{c}\text { Pink flower, wedge-shaped green leaf, red } \\
\text { stem }\end{array}$ \\
\hline 6 & Kedah & Nursery, Kedah & $06^{\circ} 11^{\prime}$ & $100^{\circ} 37^{\prime}$ & $\begin{array}{c}\text { Yellow flower, wedge-shaped green leaf, } \\
\text { red stem }\end{array}$ \\
\hline 7 & Kedah & Nursery, Kedah & $06^{\circ} 11^{\prime}$ & $100^{\circ} 37^{\prime}$ & $\begin{array}{c}\text { Purple flower, paddle-shaped green leaf, } \\
\text { red stem }\end{array}$ \\
\hline 8 & Selangor & Sungai Buloh & $03^{\circ} 19^{\prime}$ & $101^{\circ} 59^{\prime}$ & $\begin{array}{l}\text { White-pink colored flower, wedge-shaped } \\
\text { green leaf, red stem }\end{array}$ \\
\hline 9 & Selangor & Sungai Buloh & $03^{\circ} 19^{\prime}$ & $101^{\circ} 59^{\prime}$ & $\begin{array}{l}\text { Yellow-colored flower, paddle-shaped } \\
\text { green leaf, red stem }\end{array}$ \\
\hline 10 & Selangor & Sungai Buloh & $03^{\circ} 19^{\prime}$ & $101^{\circ} 59^{\prime}$ & $\begin{array}{l}\text { Pink-colored flower, wedge-shaped } \\
\text { margin red green leaf, red stem }\end{array}$ \\
\hline 11 & Selangor & AgroBio. UPM & $02^{\circ} 98^{\prime}$ & $101^{\circ} 73^{\prime}$ & $\begin{array}{l}\text { Yellow-colored flower, red margin } \\
\text { wedge-shaped green leaf, red stem }\end{array}$ \\
\hline 12 & N. Sembilan & Kg. Ayer Meleleh & $02^{\circ} 54^{\prime}$ & $101^{\circ} 80^{\prime}$ & $\begin{array}{l}\text { Wild, yellow flower, paddle-shaped green } \\
\text { leaf, red green stem }\end{array}$ \\
\hline 13 & Selangor & Food Sci. UPM & $03^{\circ} 01^{\prime}$ & $101^{\circ} 706^{\prime}$ & $\begin{array}{l}\text { Wild, yellow-colored flower, } \\
\text { wedge-shaped green leaf, green-red stem }\end{array}$ \\
\hline
\end{tabular}

sensitivity of antioxidant properties the fresh samples were oven-dried at $45-50^{\circ} \mathrm{C}$ for one week then ground and stored in $-20^{\circ} \mathrm{C}$ freezer until analysis. And for mineral analysis the samples were oven-dried at $70^{\circ} \mathrm{C}$ for 3 days $(72 \mathrm{~h}$ ) then ground and stored in plastic vials.

2.4. Chemicals and Reagents. 2,2-Diphenyl-1-picrylhydrazyl solution (DPPH), 2,4,6-tripyridyls-triazine (TPTZ), acetate buffer, ferric chloride $\left(\mathrm{FeCl}_{3} \cdot \mathrm{H}_{2} \mathrm{O}\right)$, sodium acetate hydrate $\left(\mathrm{C}_{2} \mathrm{H}_{3} \mathrm{NaO}_{2} \cdot 3 \mathrm{H}_{2} \mathrm{O}\right)$, aluminum chloride $\left(\mathrm{AlCl}_{3} \cdot 6 \mathrm{H}_{2} \mathrm{O}\right)$, sodium hydroxide $(\mathrm{NaOH})$, citric acid and 6-hydroxy-2,5,7,8tetramethylchromane-2-carboxylic acid (Trolox), and Rutin $\left(\mathrm{C}_{27} \mathrm{H}_{30} \mathrm{O}_{16}\right)$ were purchased from Sigma-Aldrich Co. (St. Louis, USA); methanol and hexane analytical grade were obtained from HmbG Chemical Co. (Germany); Folin-Ciocalteu reagent and gallic acid were from Merck Co. (Darmstadt, Germany). Sodium carbonate $\left(\mathrm{Na}_{2} \mathrm{CO}_{3}\right)$ and sodium nitrite $\left(\mathrm{NaNO}_{2}\right)$ were purchased from System Co. (USA). BHA (butylated hydroxyanisole), $\alpha$-tocopherol $\left(\mathrm{C}_{29} \mathrm{H}_{50} \mathrm{O}_{2}\right)$, hydrochloric acid $(\mathrm{HCl})$, sulfuric acid $\left(\mathrm{H}_{2} \mathrm{SO}_{4}\right)$, and hydrogen peroxide $\left(\mathrm{H}_{2} \mathrm{O}_{2}\right)$ were purchased from Fischer Scientific Co. (Leicestershire, UK).

2.5. Sample Preparation and Extraction. Three grams of powdered samples was weighted and placed in $100 \mathrm{~mL}$ conical flask and $30 \mathrm{~mL}$ of methanol was added with the ratio of $1: 10(\mathrm{w} / \mathrm{v})$ and left for 2 hours in water bath shaker with
$100 \mathrm{rpm}$ at temperature $40 \pm 1^{\circ} \mathrm{C}$ [14]. The filtrate was separated from the residue by filtering through a filter paper (Whatman number 1) and the residue was reextracted again with fresh solvent according to the procedure mentioned above. The filtrates were pooled and excess methanol was then evaporated off under reduced pressure using a rotatory evaporator (Buchi Rotavapor R-210, Switzerland). The concentrated extract was then stored at $-20 \pm 1^{\circ} \mathrm{C}$ prior to analyses. The extracts were prepared by the method described by Crozier et al. [15] with slight modifications.

\subsection{Determination of Antioxidant Compounds}

2.6.1. Determination of Total Phenolic Compounds (TPC). The TPC were determined using Folin-Ciocalteu method as reported by Singleton et al. [16] with some modifications. $0.5 \mathrm{~mL}$ of sample extract at concentration $1 \mathrm{mg} / \mathrm{mL}$ was mixed with $0.5 \mathrm{~mL}$ Folin-Ciocalteu reagent, followed by addition of $10 \mathrm{~mL}$ of $7 \%$ sodium carbonate solution. The mixture was allowed to stand for 1 hour at $25 \pm 2^{\circ} \mathrm{C}$ in the dark condition and then absorbance was measured at $725 \mathrm{~nm}$ using a UVVis Spectrophotometer (UV-1650 PC Spectrophotometer, Shimadzu, Japan). The amount of TPC was expressed as milligram of gallic acid equivalent (GAE) per g of dry weight of sample.

2.6.2. Determination of Total Flavonoid Content (TFC). Total flavonoid content was determined using a colorimetric 
method described by Abu Bakar et al. [17]. $0.5 \mathrm{~mL}$ of sample extract was mixed with $2.25 \mathrm{~mL}$ of distilled water in a test tube followed by addition of $0.15 \mathrm{~mL}$ of $5 \% \mathrm{NaNO}_{2}$ solution. After $6 \mathrm{~min}, 0.3 \mathrm{~mL}$ of a $10 \% \mathrm{AlCl}_{3} \cdot 6 \mathrm{H}_{2} \mathrm{O}$ solution was added and immediately $1.0 \mathrm{~mL}$ of $1 \mathrm{M} \mathrm{NaOH}$ was added. The mixture was mixed well by vortex. The absorbance was measured immediately at $510 \mathrm{~nm}$ with a spectrophotometer. Results were expressed as milligrams of Rutin equivalent in $1 \mathrm{~g}$ of sample (mg RE g ${ }^{-1} \mathrm{DW}$ ).

\subsubsection{Determination of Total Carotenoid Content (TCC).} Total carotenoid content was determined based on the method of Khoo et al. [18] with slight modifications. $0.5 \mathrm{~g}$ of dried powered sample was mixed with $15 \mathrm{~mL}$ hexane, then vortexed and left for few minutes, and then centrifuged for 1 minute at $3000 \mathrm{rpm}$. Supernatant was collected and reextracted until it became colorless. Collected supernatant was evaporated until being dried using rotary evaporator at $40^{\circ} \mathrm{C}$. Crude extract was redissolved in $5 \mathrm{~mL}$ hexane and absorbances were read at $450 \mathrm{~nm}$ UV spectrophotometer (UV-1650 PC Spectrophotometer, Shimadzu, Japan). Results were expressed as milligrams of $\beta$-carotene equivalent in $1 \mathrm{~g}$ of sample ( $\left.\mathrm{mg} \mathrm{BCE} \mathrm{g}^{-1} \mathrm{DW}\right)$.

\subsection{Determination of Antioxidant Activity}

2.7.1. 1,1-Diphenyl-2-picrylhydrazyl (DPPH) Free Radical Scavenging Activity. Diphenyl-2-picrylhydrazyl (DPPH) assay was used to determine the free radical scavenging activity according to the method of Brand-Williams et al. [19] with some modifications. Sample solutions with different concentrations $(0.156 \mathrm{mg} / \mathrm{mL}$ to $10 \mathrm{mg} / \mathrm{mL})$ were prepared from purslane extract. An aliquot of each concentration $(0.25 \mathrm{~mL})$ was mixed with $1.75 \mathrm{~mL}$ of DPPH solution $(0.025 \mathrm{mg} / \mathrm{mL})$. The mixture was then left at room temperature for 30 minutes in the dark. Butylated hydroxyanisole (BHA) and $\alpha$-tocopherol at concentrations 100 and $200 \mathrm{ppm}$ were used as a standard, respectively. The absorbance of the mixture was measured at wavelength $515 \mathrm{~nm}$ using microplate reader (Model EL-800, BIOTEK Instrument, USA). $\mathrm{IC}_{50}$ value, representing the amount of extract which scavenged/reduced $50 \%$ of the DPPH radical, was calculated from percent scavenging versus concentration curve. A higher concentration to reduce $50 \%$ of DPPH solution showed lower antioxidant activity. The calculation of $\% \mathrm{DPPH}$ free radical scavenging is as follows:

\section{$\%$ Scavenging}

$$
\begin{aligned}
= & \frac{\text { Absorbance of control }- \text { Absorbance of sample }}{\text { Absorbance of control }} \\
& \times 100 \% \text {. }
\end{aligned}
$$

2.7.2. Ferric Reducing Antioxidant Power (FRAP) Assay. FRAP assay was conducted based on the method as described by Benzie and Strain [20] with minor modifications. The oxidant in the FRAP assay was prepared by mixing $2.5 \mathrm{~mL}$ of $10 \mathrm{mM}$ TPTZ prepared in $40 \mathrm{mM} \mathrm{HCl}, 25 \mathrm{~mL}$ of acetate buffer, and $2.5 \mathrm{~mL}$ of $20 \mathrm{mM} \mathrm{FeCl} \cdot \mathrm{H}_{2} \mathrm{O}$. The mixture was referred to as "FRAP reagent." $200 \mu \mathrm{L}$ of sample was pipetted into a test tube and mixed with $3 \mathrm{~mL}$ of FRAP reagent by vortexing. The mixture was allowed to react for 30 minutes at temperature of $37^{\circ} \mathrm{C}$. Absorbance of the mixture was then read at $594 \mathrm{~nm}$. Triplicate tubes were prepared for each extract. The FRAP values expressed in mg Trolox per g were derived from the standard curve.

2.7.3. Chemical Analysis of Purslane Samples. Plant samples were dried in an oven at $70^{\circ} \mathrm{C}$ for $72 \mathrm{~h}$. Oven-dried samples of purslane were ground and stored in plastic vials until analysis. The $\mathrm{N}, \mathrm{P}, \mathrm{K}, \mathrm{Na}, \mathrm{Ca}, \mathrm{Mg}, \mathrm{Fe}, \mathrm{Zn}$, and $\mathrm{Mn}$ contents were analyzed using the digestion method [21] and determined using an Atomic Absorption Spectrophotometer (AAS; Perkin Elmer, 5100, USA). For this purpose the grinded powdered samples of $0.25 \mathrm{~g}$ were weighed and poured into a digestion tube. Then $5 \mathrm{~mL}$ of concentrated sulfuric acid $\left(\mathrm{H}_{2} \mathrm{SO}_{4}\right)$ was added and kept for overnight or at least 2 hours until the plant materials moistened properly. Then $2 \mathrm{~mL}$ of $50 \%$ hydrogen peroxide $\left(\mathrm{H}_{2} \mathrm{O}_{2}\right)$ was added slowly and the digestion tube was placed in a digestion block where the digester block was set to heat for 45 minutes. After 45 minutes the tube was removed and allowed to cool and $2 \mathrm{~mL}$ of $50 \%$ $\mathrm{H}_{2} \mathrm{O}_{2}$ was added again, kept for heating, and cooling process was repeated until the digested solution became colorless or clear. The cleared cool sample was then filtered and the final volume was made $100 \mathrm{~mL}$ by adding distilled water for analysis.

2.8. Statistical Analysis. Analysis of variance (ANOVA) procedure in SAS (Version 9.2) [22] was used with a completely randomized design; LSD test was performed to compare the data. All determinations were done at least in triplicates and all were averaged. The confidence limits used in this study were based on $95 \%(P<0.05)$.

\section{Results}

3.1. Total Phenolic Compounds, Total Flavonoid Contents, and Total Carotenoid Contents. In this study, TPC were determined compared with standard gallic acid, and results are expressed in terms of milligrams of gallic acid equivalent (mg GAE/g dry sample) (Std. curve Figure 2(a)). Total flavonoid content (TFC) was expressed in milligrams of rutin equivalent (mg RE/g dry sample) (Std. curve Figure 2(b)). And total carotenoid content (TFC) was expressed in milligrams of $\beta$-carotene equivalent (mg BCE/g dry sample) (Std. curve Figure 2(c)).

The TPC, TFC, and TCC values for purslane fraction extracts are presented in Table 2 . Among all 13 accessions, the highest amount of TPC (9.12 mg/g DW) was found in accessions V8 and the highest amount of TFC (1.44 mg/g DW) was determined in accessions V10, whereas the highest amount of TCC (5.64 mg/g DW) was found in accessions V4, respectively. 
TABLe 2: Total phenolic compounds, flavonoid content, and total carotenoid content of 13 accessions of Portulaca oleracea.

\begin{tabular}{lccc}
\hline Accessions & TPC $^{\mathrm{l}}$ & TFC $^{2}$ & TCC $^{3}$ \\
\hline V1 & $4.28 \pm 0.42^{\mathrm{c}}$ & $0.45 \pm 0.03^{\mathrm{de}}$ & $1.57 \pm 0.14^{\mathrm{i}}$ \\
V2 & $2.64 \pm 0.24^{\mathrm{gh}}$ & $0.55 \pm 0.03^{\mathrm{d}}$ & $2.65 \pm 0.11^{\mathrm{de}}$ \\
V3 & $2.21 \pm 2.16^{\mathrm{h}}$ & $1.18 \pm 0.07^{\mathrm{b}}$ & $3.52 \pm 0.04^{\mathrm{b}}$ \\
V4 & $2.67 \pm 0.08^{\mathrm{fg}}$ & $1.21 \pm 0.04^{\mathrm{b}}$ & $5.64 \pm 0.09^{\mathrm{a}}$ \\
V5 & $0.96 \pm 0.04^{\mathrm{j}}$ & $0.37 \pm 0.03^{\mathrm{e}}$ & $2.05 \pm 0.32^{\mathrm{gh}}$ \\
V6 & $4.1 \pm 0.16^{\mathrm{cd}}$ & $0.37 \pm 0.04^{\mathrm{e}}$ & $1.43 \pm 0.16^{\mathrm{i}}$ \\
V7 & $3.69 \pm 0.17^{\mathrm{de}}$ & $0.89 \pm 0.021^{\mathrm{c}}$ & $2.29 \pm 0.11^{\mathrm{fg}}$ \\
V8 & $9.12 \pm 0.29^{\mathrm{a}}$ & $1.41 \pm 0.04^{\mathrm{a}}$ & $2.41 \pm 0.29^{\mathrm{ef}}$ \\
V9 & $1.64 \pm 0.16^{\mathrm{i}}$ & $0.13 \pm 0.04^{\mathrm{f}}$ & $0.68 \pm 0.01^{\mathrm{j}}$ \\
V10 & $6.58 \pm 0.21^{\mathrm{b}}$ & $1.44 \pm 0.08^{\mathrm{a}}$ & $3.05 \pm 0.25^{\mathrm{c}}$ \\
V11 & $3.38 \pm 0.04^{\mathrm{f}}$ & $0.47 \pm 0.01^{\mathrm{de}}$ & $2.84 \pm 0.34^{\mathrm{cd}}$ \\
V12 & $6.98 \pm 0.61^{\mathrm{b}}$ & $0.94 \pm 0.07^{\mathrm{c}}$ & $1.88 \pm 0.05^{\mathrm{h}}$ \\
V13 & $2.22 \pm 0.22^{\mathrm{h}}$ & $0.54 \pm 0.04^{\mathrm{d}}$ & $0.52 \pm 0.06^{\mathrm{j}}$ \\
\hline
\end{tabular}

${ }^{1}$ mg GAE/g DW. ${ }^{2}$ mg rutin equivalent $\mathrm{g}^{-1}$ DW. ${ }^{3} \mathrm{mg} \beta$-carotene equivalent $\mathrm{g}^{-1} \mathrm{DW}$.

Means followed by the same letter within a column are not significantly different at $P \leq 0.05$ (LSD).

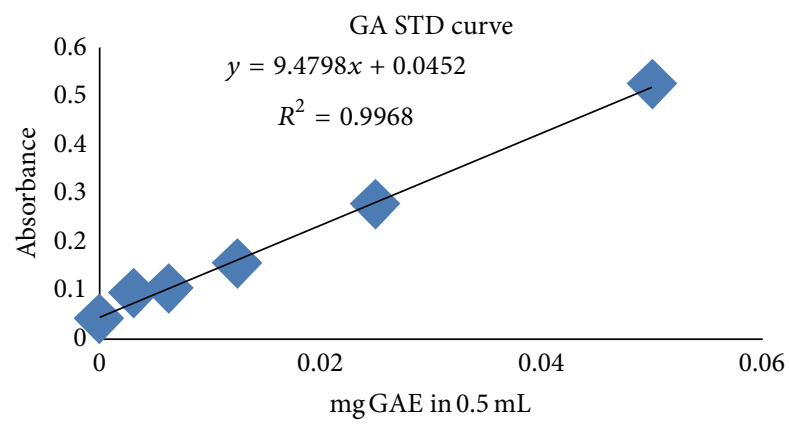

(a)

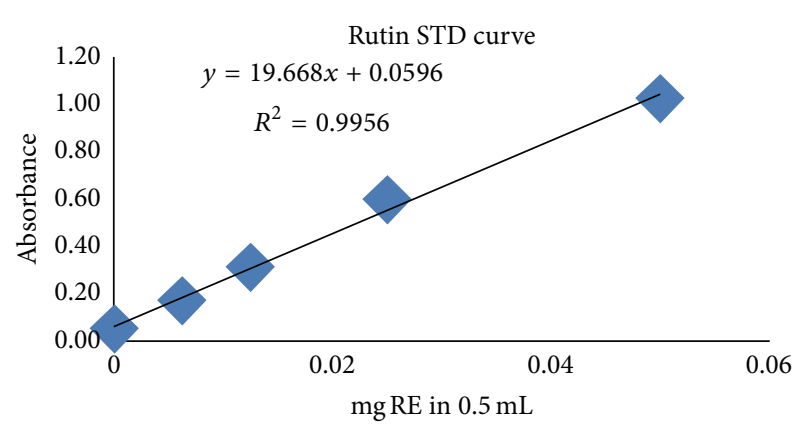

(b)

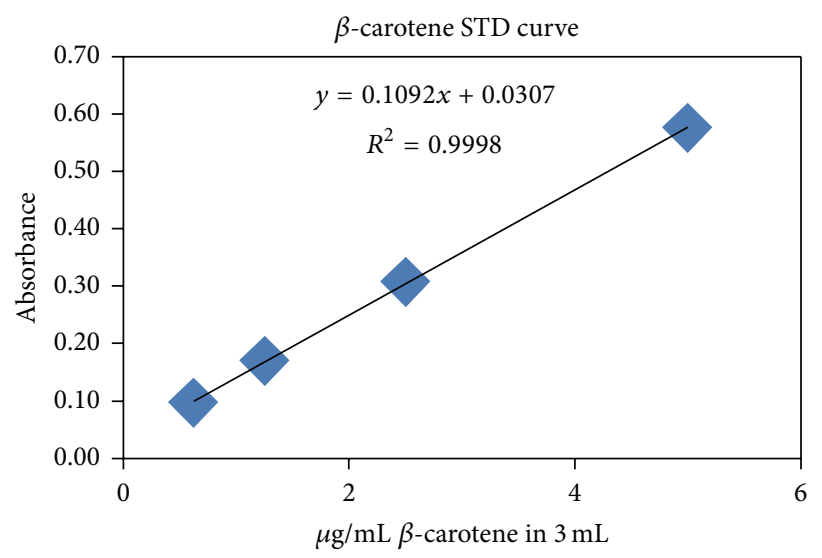

(c)

Figure 2: Standard curve of GA (for TPC), Rutin (for TFC), and $\beta$-carotene (for TCC).

\subsection{Antioxidant Activity of Purslane}

3.2.1. DPPH Free Radical Scavenging Activity. Antioxidant activity of purslane extract that was measured by $\mathrm{DPPH}$ assay is presented in Table 3 with the regression equation $\left(r^{2}\right)$ of BHA and tocopherol standard curve. $\mathrm{IC}_{50}$ value for the 13 accessions of purslane extract in the present study was determined and varied between $2.52 \pm 0.03 \mathrm{mg} / \mathrm{mL}$ and $3.29 \pm 0.01 \mathrm{mg} / \mathrm{mL}$ indicating the highest antioxidant activity $(2.52 \mathrm{mg} / \mathrm{mL})$ shown by the purslane accession V12, whereas the lowest $(3.29 \mathrm{mg} / \mathrm{mL})$ was found in accession V9 among all the 13 accessions. 
TABLE 3: 1,1-Diphenyl-2-picrylhydrazyl (DPPH) radical-scavenging activity of 13 different accessions of purslane.

\begin{tabular}{lccc}
\hline Purslane accessions & Inhibition $\pm \mathrm{SD}(\%)$ & Regression equation $\left(r^{2}\right)$ & $\mathrm{IC}_{50}^{\mathrm{a}, \mathrm{b}}\left(\mathrm{mg} \mathrm{mL}^{-1}\right)$ \\
\hline V1 & $59.54 \pm 0.39^{\mathrm{c}}$ & $y=48.72 x-94.03\left(r^{2}=0.852\right)$ & $2.95 \pm 0.01^{\mathrm{c}}$ \\
V2 & $48.63 \pm 0.33^{\mathrm{g}}$ & $y=55.89 x-94.12\left(r^{2}=0.962\right)$ & $2.58 \pm 0.01^{\mathrm{h}}$ \\
V3 & $66.81 \pm 0.56^{\mathrm{a}}$ & $y=52.89 x-100.3\left(r^{2}=0.917\right)$ & $2.83 \pm 0.02^{\mathrm{e}}$ \\
V4 & $60.59 \pm 0.67^{\mathrm{b}}$ & $y=45.68 x-83.84\left(r^{2}=0.893\right)$ & $2.92 \pm 0.02^{\mathrm{d}}$ \\
V5 & $41.30 \pm 0.38^{\mathrm{i}}$ & $y=55.73 x-100.3\left(r^{2}=0.929\right)$ & $2.70 \pm 0.01^{\mathrm{f}}$ \\
V6 & $53.18 \pm 0.25^{\mathrm{e}}$ & $y=53.36 x-114.6\left(r^{2}=0.926\right)$ & $3.09 \pm 0.01^{\mathrm{b}}$ \\
V7 & $50.61 \pm 0.29^{\mathrm{f}}$ & $y=52.89 x-84.49\left(r^{2}=0.965\right)$ & $2.54 \pm 0.04^{\mathrm{ij}}$ \\
V8 & $50.66 \pm 0.46^{\mathrm{f}}$ & $y=53.28 x-84.59\left(r^{2}=0.962\right)$ & $2.54 \pm 0.01^{\mathrm{ij}}$ \\
V9 & $41.25 \pm 0.11^{\mathrm{i}}$ & $y=58.23 x-142.1\left(r^{2}=0.950\right)$ & $3.29 \pm 0.01^{\mathrm{a}}$ \\
V10 & $44.04 \pm 0.38^{\mathrm{h}}$ & $y=59.58 x-107.4\left(r^{2}=0.937\right)$ & $2.65 \pm 0.01^{\mathrm{g}}$ \\
V11 & $57.80 \pm 0.13^{\mathrm{d}}$ & $y=47.33 x-91.20\left(r^{2}=0.857\right)$ & $2.98 \pm 0.00^{\mathrm{c}}$ \\
V12 & $51.35 \pm 1.64^{\mathrm{f}}$ & $y=58.46 x-97.53\left(r^{2}=0.936\right)$ & $2.52 \pm 0.03^{\mathrm{j}}$ \\
V13 & $49.24 \pm 0.35^{\mathrm{g}}$ & $y=53.97 x-87.96\left(r^{2}=0.935\right)$ & $2.56 \pm 0.01^{\mathrm{hi}}$ \\
\hline
\end{tabular}

${ }^{a}$ Concentration of sample required to scavenge $50 \%$ of free radicals or to prevent lipid peroxidation by $50 \%$.

${ }^{\mathrm{b}}$ Means with different letters in the same column are significantly different at $P<0.05$.

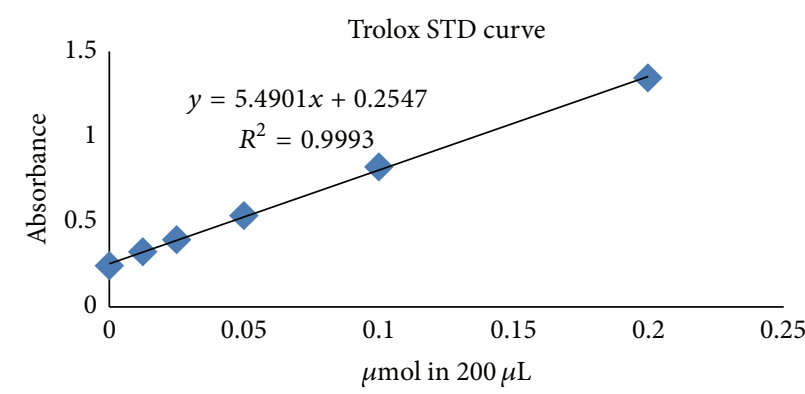

(a)

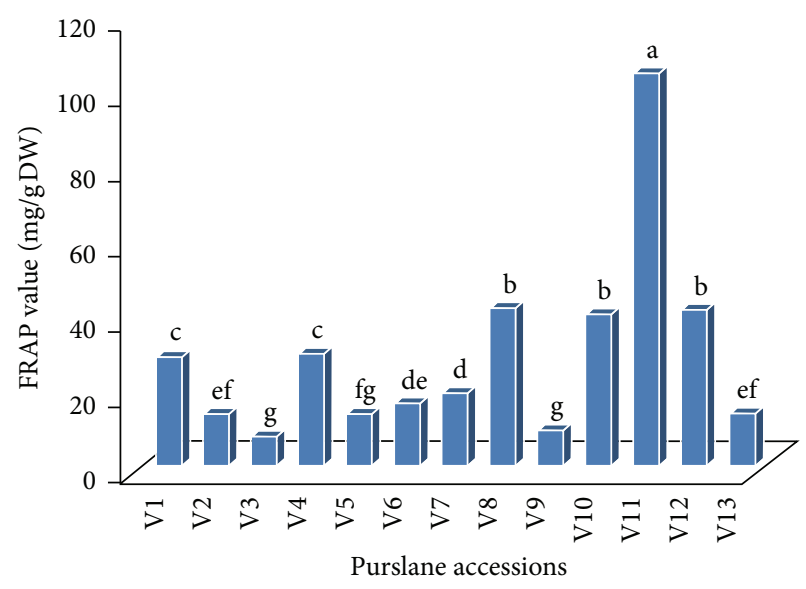

(b)

FIGURE 3: Trolox standard curve with FRAP assayed value. Means followed by the same letter within a column are not significantly different at $P \leq 0.05$ (LSD).

3.2.2. Ferric-Reducing Antioxidant Power (FRAP) Assay. The ferric-reducing antioxidant power (FRAP) values were measured from all the 13 collected purslane extracts and expressed in mg Trolox per g (Figure 3(a)). There was a significant difference among the FRAP values and they ranged between $104.2 \pm 6.34 \mathrm{mg} / \mathrm{g} \mathrm{DW}$ and $7.39 \pm 0.08 \mathrm{mg} / \mathrm{g} \mathrm{DW}$ as shown in Figure 3(b).

3.3. Mineral Composition. Results represented significant variations $(P<0.05)$ in macrominerals $(\mathrm{N}, \mathrm{P}, \mathrm{K}, \mathrm{Na}, \mathrm{Ca}$, and $\mathrm{Mg}$ ) and microminerals (Fe, $\mathrm{Zn}$, and $\mathrm{Mn}$ ) among all the 13 purslane accessions (Tables 4 and 5).

Maximum concentration of macrominerals $\mathrm{N}, \mathrm{P}, \mathrm{K}, \mathrm{Na}$, $\mathrm{Ca}$, and $\mathrm{Mg}(184.6 \pm 0.84,14.18 \pm 0.22,656 \pm 14,154.4 \pm$ $0.22,104.2 \pm 0.28$, and $101.4 \pm 1.46 \mathrm{~g} / \mathrm{kg} \mathrm{DW}$ ) was produced by the accessions V12, V13, V11, V11, V6, and V1, respectively, and the minimum of $\mathrm{N}, \mathrm{P}, \mathrm{K}, \mathrm{Na}, \mathrm{Ca}$, and $\mathrm{Mg}(79.3 \pm 16.14$, $5.08 \pm 0.24,266 \pm 12,52.4 \pm 1.9,35 \pm 0.56$, and $40.8 \pm$ $0.5)$ was found in accessions V4, V4, V1, V1, V10, and V2, respectively. Regarding the microelements iron $(\mathrm{Fe})$ content ranged between $11.1 \pm 0.18$ and $1.86 \pm 0.18 \mathrm{~g} / \mathrm{kg} \mathrm{DW}$ (V6 and $\mathrm{V} 7)$, zinc ( $\mathrm{Zn}) 1.48 \pm 0.12$ and $0.62 \pm 0.06$ (V12 and V9), and manganese $(\mathrm{Mn}) 1.64 \pm 0.26$ and $0.14 \pm 0.04 \mathrm{~g} / \mathrm{kg} \mathrm{DW}(\mathrm{V} 12$ and V5 also V7), respectively.

The correlation analysis of the selected macro- and micromineral showed that similar parameter has a highly significant correlation, while among other parameters the correlation is either nonsignificant or less significant or has moderate relation (Table 6). 
TABLE 4: Selected macromineral composition of 13 collected purslane accessions (on dry weight basis $\mathrm{g} / \mathrm{kg}$ ).

\begin{tabular}{lcccccc}
\hline Purslane accessions & $\mathrm{N}$ & $\mathrm{P}$ & $\mathrm{K}$ & $\mathrm{Na}$ & $\mathrm{Ca}$ & $\mathrm{Mg}$ \\
\hline V1 & $97.2 \pm 11.6^{\mathrm{e} *}$ & $6.32 \pm 0.18^{\mathrm{i}}$ & $266 \pm 12^{\mathrm{h}}$ & $52.4 \pm 1.9^{\mathrm{l}}$ & $68.4 \pm 0.56^{\mathrm{f}}$ & $101.4 \pm 1.46^{\mathrm{a}}$ \\
V2 & $123.6 \pm 8.8^{\mathrm{d}}$ & $7.34 \pm 0.18^{\mathrm{g}}$ & $304 \pm 20^{\mathrm{g}}$ & $92.4 \pm 0.22^{\mathrm{d}}$ & $48.54 \pm 2.3^{\mathrm{i}}$ & $40.8 \pm 0.5^{\mathrm{k}}$ \\
V3 & $84 \pm 8.46^{\mathrm{b}}$ & $7.48 \pm 0.26^{\mathrm{g}}$ & $462 \pm 18^{\mathrm{de}}$ & $64 \pm 0.14^{\mathrm{j}}$ & $82 \pm 0.5^{\mathrm{b}}$ & $91.4 \pm 0.22^{\mathrm{c}}$ \\
V4 & $79.3 \pm 16.14^{\mathrm{b}}$ & $5.08 \pm 0.24^{\mathrm{j}}$ & $574 \pm 12^{\mathrm{c}}$ & $57.4 \pm 0.28^{\mathrm{k}}$ & $52 \pm 0.26^{\mathrm{h}}$ & $95.8 \pm 0.26^{\mathrm{b}}$ \\
V5 & $142 \pm 0.52^{\mathrm{c}}$ & $8.44 \pm 0.16^{\mathrm{d}}$ & $502 \pm 12^{\mathrm{c}}$ & $86.6 \pm 0.22^{\mathrm{f}}$ & $64.04 \pm 0.56^{\mathrm{f}}$ & $71.8 \pm 0.54^{\mathrm{f}}$ \\
V6 & $140.3 \pm 1.72^{\mathrm{c}}$ & $8.22 \pm 0.26^{\mathrm{e}}$ & $412 \pm 6^{\mathrm{f}}$ & $85.2 \pm 0.34^{\mathrm{g}}$ & $104.2 \pm 0.28^{\mathrm{a}}$ & $79.6 \pm 0.34^{\mathrm{d}}$ \\
V7 & $136.89 \pm 1.72^{\mathrm{c}}$ & $6.72 \pm 0.14^{\mathrm{h}}$ & $448 \pm 12^{\mathrm{e}}$ & $123 \pm 0.18^{\mathrm{b}}$ & $66.4 \pm 0.26^{\mathrm{g}}$ & $68.8 \pm 0.32^{\mathrm{g}}$ \\
V8 & $183.4 \pm 0.92^{\mathrm{a}}$ & $10.74 \pm 0.16^{\mathrm{c}}$ & $414 \pm 12^{\mathrm{f}}$ & $69.8 \pm 0.36^{\mathrm{h}}$ & $70.4 \pm 0.18^{\mathrm{e}}$ & $68.2 \pm 0.42^{\mathrm{g}}$ \\
V9 & $117.2 \pm 1.36^{\mathrm{d}}$ & $11.4 \pm 0.22^{\mathrm{b}}$ & $502 \pm 18^{\mathrm{c}}$ & $63.8 \pm 0.36^{\mathrm{j}}$ & $75.4 \pm 0.44^{\mathrm{d}}$ & $74.2 \pm 0.32^{\mathrm{e}}$ \\
V10 & $167.2 \pm 1.08^{\mathrm{b}}$ & $6.2 \pm 0.18^{\mathrm{i}}$ & $478 \pm 16^{\mathrm{d}}$ & $66.8 \pm 0.26^{\mathrm{i}}$ & $35 \pm 0.56^{\mathrm{l}}$ & $78.46 \pm 2.04^{\mathrm{d}}$ \\
V11 & $105.24 \pm 0.88^{\mathrm{e}}$ & $7.7 \pm 0.14^{\mathrm{f}}$ & $656 \pm 14^{\mathrm{a}}$ & $154.4 \pm 0.22^{\mathrm{a}}$ & $76.78 \pm 0.24^{\mathrm{c}}$ & $51.62 \pm 0.26^{\mathrm{h}}$ \\
V12 & $184.6 \pm 0.84^{\mathrm{a}}$ & $8.3 \pm 0.22^{\mathrm{de}}$ & $478 \pm 14^{\mathrm{d}}$ & $97.2 \pm 0.34^{\mathrm{c}}$ & $43.2 \pm 0.34^{\mathrm{j}}$ & $46 \pm 0.38^{\mathrm{j}}$ \\
V13 & $118.94 \pm 0.64^{\mathrm{d}}$ & $14.18 \pm 0.22^{\mathrm{a}}$ & $586 \pm 16^{\mathrm{b}}$ & $88.78 \pm 0.26^{\mathrm{e}}$ & $37 \pm 0.32^{\mathrm{k}}$ & $49.6 \pm 0.22^{\mathrm{i}}$ \\
\hline
\end{tabular}

Means followed by the same letter within a column are not significantly different at $P \leq 0.05$ (LSD).

${ }^{*}$ Average of triplicate determinations $\pm \mathrm{SD}$ (standard deviation).

TABLE 5: Selected micromineral composition of 13 collected purslane accessions (on dry weight basis g/kg).

\begin{tabular}{lccr}
\hline Purslane accessions & Fe & Zn & Mn \\
\hline V1 & $5.14 \pm 0.22^{\mathrm{e}}$ & $0.86 \pm 0.10^{\mathrm{cd}}$ & $0.34 \pm 0.12^{\mathrm{gh}}$ \\
V2 & $5.26 \pm 0.28^{\mathrm{e}}$ & $0.82 \pm 0.04^{\mathrm{e}}$ & $0.42 \pm 0.08^{\mathrm{g}}$ \\
V3 & $5.72 \pm 0.22^{\mathrm{d}}$ & $0.8 \pm 0.08^{\mathrm{d}-\mathrm{f}}$ & $1.06 \pm 0.12^{\mathrm{c}-\mathrm{e}}$ \\
V4 & $3.38 \pm 0.18^{\mathrm{g}}$ & $0.7 \pm 0.12^{\mathrm{e}-\mathrm{g}}$ & $0.24 \pm 0.06^{\mathrm{gh}}$ \\
V5 & $2.9 \pm 0.28^{\mathrm{h}}$ & $0.98 \pm 0.06^{\mathrm{bc}}$ & $0.14 \pm 0.06^{\mathrm{h}}$ \\
V6 & $11.1 \pm 0.18^{\mathrm{a}}$ & $0.92 \pm 0.10^{\mathrm{b}-\mathrm{d}}$ & $0.68 \pm 0.14^{\mathrm{f}}$ \\
V7 & $1.86 \pm 0.18^{\mathrm{i}}$ & $0.66 \pm 0.08^{\mathrm{fg}}$ & $0.14 \pm 0.04^{\mathrm{h}}$ \\
V8 & $6.14 \pm 0.26^{\mathrm{d}}$ & $0.84 \pm 0.08^{\mathrm{c}-\mathrm{e}}$ & $1.36 \pm 0.22^{\mathrm{b}}$ \\
V9 & $4.28 \pm 0.22^{\mathrm{f}}$ & $0.62 \pm 0.06^{\mathrm{g}}$ & $1.12 \pm 0.18^{\mathrm{cd}}$ \\
V10 & $3.96 \pm 0.30^{\mathrm{f}}$ & $0.88 \pm 0.06^{\mathrm{cd}}$ & $0.84 \pm 0.18^{\mathrm{ef}}$ \\
V11 & $5.86 \pm 0.36^{\mathrm{d}}$ & $0.78 \pm 0.08^{\mathrm{d}-\mathrm{f}}$ & $0.94 \pm 0.24^{\mathrm{de}}$ \\
V12 & $8.66 \pm 0.20^{\mathrm{c}}$ & $1.48 \pm 0.12^{\mathrm{a}}$ & $1.64 \pm 0.26^{\mathrm{a}}$ \\
V13 & $10.06 \pm 0.18^{\mathrm{b}}$ & $1.06 \pm 0.10^{\mathrm{b}}$ & $1.18 \pm 0.20^{\mathrm{bc}}$ \\
\hline
\end{tabular}

Means followed by the same letter within a column are not significantly different at $P \leq 0.05$ (LSD).

${ }^{*}$ Average of triplicate determinations $\pm \mathrm{SD}$ (standard deviation).

TABLE 6: Pearson's correlation coefficient among different mineral nutrients of purslane.

\begin{tabular}{|c|c|c|c|c|c|c|c|c|c|}
\hline Factors & $\mathrm{N}$ & $\mathrm{P}$ & $\mathrm{K}$ & $\mathrm{Na}$ & $\mathrm{Ca}$ & $\mathrm{Mg}$ & $\mathrm{Zn}$ & $\mathrm{Fe}$ & $\mathrm{Mn}$ \\
\hline $\mathrm{N}$ & 1 & & & & & & & & \\
\hline $\mathrm{P}$ & $-0.11 \mathrm{~ns}$ & 1 & & & & & & & \\
\hline K & $0.05 \mathrm{~ns}$ & $0.25 \mathrm{~ns}$ & 1 & & & & & & \\
\hline $\mathrm{Na}$ & $-0.25 \mathrm{~ns}$ & $0.02 \mathrm{~ns}$ & $0.42 \mathrm{~ns}$ & 1 & & & & & \\
\hline $\mathrm{Ca}$ & $-0.17 \mathrm{~ns}$ & $-0.06 \mathrm{~ns}$ & $-0.12 \mathrm{~ns}$ & $0.08 \mathrm{~ns}$ & 1 & & & & \\
\hline $\mathrm{Mg}$ & $0.04 \mathrm{~ns}$ & $-0.43 \mathrm{~ns}$ & -0.20 & $-0.65^{*}$ & $0.36 \mathrm{~ns}$ & 1 & & & \\
\hline $\mathrm{Zn}$ & $0.37 \mathrm{~ns}$ & $0.20 \mathrm{~ns}$ & $0.01 \mathrm{~ns}$ & $0.07 \mathrm{~ns}$ & $-0.36 \mathrm{~ns}$ & $-0.43 \mathrm{~ns}$ & 1 & & \\
\hline $\mathrm{Fe}$ & $0.04 \mathrm{~ns}$ & $0.49 \mathrm{~ns}$ & $0.03 \mathrm{~ns}$ & $0.05 \mathrm{~ns}$ & $0.14 \mathrm{~ns}$ & $-0.31 \mathrm{~ns}$ & $0.57^{*}$ & 1 & \\
\hline Mn & $0.39 \mathrm{~ns}$ & $0.56^{*}$ & $0.24 \mathrm{~ns}$ & $0.01 \mathrm{~ns}$ & $-0.12 \mathrm{~ns}$ & $-0.38 \mathrm{~ns}$ & $0.49 \mathrm{~ns}$ & $0.58^{*}$ & 1 \\
\hline
\end{tabular}

Here $\mathrm{N}, \mathrm{P}, \mathrm{K}, \mathrm{Na}, \mathrm{Ca}, \mathrm{Mg}, \mathrm{Zn}, \mathrm{Fe}$, and $\mathrm{Mn}$ indicate nitrogen, phosphorus, potassium, sodium, calcium, magnesium, zinc, iron, and manganese, respectively. ${ }^{*} 0.05>P>0.01$; ns: not significant; -: negative correlation at $0.05 \%$ level. 


\section{Discussion}

4.1. Total Phenolic Compounds (TPC), Total Flavonoid Contents (TFC), and Total Carotenoid Content (TCC) in Purslane. Phenolic compounds, which are widely distributed in plants [23], have gained much attention because of their antioxidant activities and ability to scavenge free radicals. Antioxidants have potential benefits to human health through their physiological activity, including antioxidant, antimutagenic, and antitumor [23, 24]. Phenolic compounds found in dietary and medicinal plants have shown potential oxidative stress inhibition $[25,26]$. Total phenol and total flavonoid content have been reported to be associated with antioxidation activity in various plants [27]. On the other hand, carotenoids are a group of phytochemicals that are responsible for different colors of the foods. They are recognized as playing an important role in the prevention of human diseases and maintaining good health especially against cardiovascular diseases and certain cancers $[28,29]$. Based on epidemiological studies a positive link is suggested between higher dietary intake and tissue concentrations of carotenoids and lower risk of chronic diseases [30-32]. The antioxidant properties of carotenoids have been suggested as being the main mechanism by which they afford their beneficial effects. Recent studies are also showing that carotenoids may mediate their effects via other mechanisms such as gap junction communication, cell growth regulation, modulating gene expression, and immune response and as modulators of Phase I and II drug metabolizing enzymes [33-36].

Thirteen collected purslane samples were analyzed in this study for the contents of total phenolic compounds (TPC), total flavonoid contents (TFC), and total carotenoid contents (TCC). Results of the study have been presented in Table 2. From the analysis results, we observed that the TPC contents ranged between $9.12 \pm 0.29 \mathrm{mg} / \mathrm{g} \mathrm{DW}$ and $0.96 \pm$ $0.04 \mathrm{mg} / \mathrm{g} \mathrm{DW}$, TFC content $1.44 \pm 0.08 \mathrm{mg} / \mathrm{g} \mathrm{DW}$ and $0.13 \pm$ $0.04 \mathrm{mg} / \mathrm{g} \mathrm{DW}$, and TCC $5.64 \pm 0.09 \mathrm{mg} / \mathrm{g} \mathrm{DW}$ and $0.52 \pm$ $0.06 \mathrm{mg} / \mathrm{g}$ DW, respectively. Uddin et al. [37] and Lim and Quah [38] also found closely similar results using methanol solvents from matured purslane plants. Among all the 13 accessions V1, V3, V9, and V11 are morphologically more or less the same; on the other hand, V2, V4, V5, and V10 are also morphologically more or less the same but collected from different locations and showed significant $(P<0.05)$ difference regarding TPC, TFC, and TCC contents but Lim and Quah [38] reported that they got near about similar results from the same cultivars collected from different places.

4.2. Antioxidant Activity Assay (DPPH and FRAP). In the present study antioxidant activity was analyzed utilizing 2,2diphenyl-1-picrylhydrazyl (DPPH) free radical scavenging capacity and ferric ion reducing antioxidant power (FRAP) assay systems and all the findings are shown in Table 3. The $\mathrm{IC}_{50}$ is defined as the concentrations required to reduce $50 \%$ of $\mathrm{DPPH}$ from the original concentration. $\mathrm{IC}_{50}$ value for the 13 accessions of purslane extract in the present study was determined and the values were varied between $2.52 \pm$ $0.03 \mathrm{mg} / \mathrm{mL}$ and $3.29 \pm 0.01 \mathrm{mg} / \mathrm{mL}$ indicating the highest antioxidant activity $(2.52 \mathrm{mg} / \mathrm{mL})$ shown by the purslane accession V12, whereas the lowest $(3.29 \mathrm{mg} / \mathrm{mL})$ was found in accession V9 among all the 13 accessions. This result is partially similar to the findings of Uddin et al. [37] and Siriamornpun and Suttajit [39] at 60 days maturity stage using $\mathrm{DPPH}$ assay. Very interestingly we found that the ornamental purslane (V1 to V11) comparatively showed the lower DPPH activity $\left(\mathrm{IC}_{50}\right.$ value) compared with both of the common purslane (V12 and V13) accessions, which represents different trends than TPC, TFC, TCC, and FRAP assays. This finding is same as the results reported by Lim and Quah [38] who worked with both types of purslane. We also found that among all the 13 accessions, V1, V3, V9, and V11 are morphologically more or less the same; on the other hand, V2, V4, V5, and V10 are also morphologically more or less the same but collected from different locations and showed significant $(P<0.05)$ difference both in \% inhibition and $\mathrm{IC}_{50}$ value. It may happen due to the effect of different geographical locations and microclimatic variations as well as variations in soil qualities.

Antioxidant activity of purslane measured by FRAP assay is presented in Figure 3(b). According to the analysis results it was found that the highest FRAP value $(104.2 \pm 6.34)$ was produced by the accession V11 and the lowest $(7.39 \pm$ $0.08 \mathrm{mg} / \mathrm{g} \mathrm{DW}$ ) was produced by the accessions V3. This finding is partially similar to the results described by Uddin et al. [37]. Here we observed the same results for V1 and V4; V8, V10, and V12; V3 and V9 and V2 and V13 for FRAP values, though they are not morphologically same but collected from different locations.

4.3. Macro- and Micro-Mineral Composition in Purslane. Vegetables are very rich source of essential biochemicals and nutrients such as carbohydrates, carotene, vitamins, calcium, iron, ascorbic acid, and palpable concentrations of trace minerals $[40,41]$. In this study significant differences $(P<$ $0.05)$ were observed for major micro- and macronutrients among different clones collected from different locations when compared with one another both in intralocational or even in interlocational. According to the analysis results it was found that potassium $(\mathrm{K})$ content was the highest among all the macro- and microminerals followed by nitrogen $(\mathrm{N})$, sodium $(\mathrm{Na})$, magnesium $(\mathrm{Mg})$, calcium $(\mathrm{Ca})$, iron $(\mathrm{Fe})$, zinc $(\mathrm{Zn})$, and manganese $(\mathrm{Mn})$, respectively. A number of reports have indicated that purslane plants contain the maximum amount of potassium $(\mathrm{K})[37,42,43]$.

Because of the reciprocal effects of $\mathrm{Na}$ and $\mathrm{K}$ authorities have argued that a high diet in potassium and low diet in sodium (low urinary $\mathrm{Na}$ and $\mathrm{K}$ ratio) favor lower blood pressure. Increase in dietary potassium as the chloride salt has shown to decrease blood pressure in some hypertensive individuals [43]. Low $\mathrm{Na}$ and high $\mathrm{K}$ diet would decrease the development of cardiovascular disease [44]. Deficiency of calcium, phosphorous, and vitamin D leads to the classic bone symptoms associated with rickets, such as bowlegs, knock knees, curvature of the spine, and pelvic and thoracic deformities [45]. Magnesium plays an important role in the structure and the function of the human body [46].

Iron has the longest and best described history among all the micronutrients. It is a key element in the metabolism of 
almost all living organisms. In humans, iron is an essential component of hundreds of proteins and enzymes [47, 48]. Manganese $(\mathrm{Mn})$ plays an important role in a number of physiological processes as a constituent of some enzymes and an activator of other enzymes [49]. Zinc plays an important role in the structure of proteins and cell membranes. Loss of zinc from biological membranes increases their susceptibility to oxidative damage and impairs their function [50].

Purslane also contains trace amount of copper $(\mathrm{Cu})$ is an essential trace element for humans and animals [51]. Copper provides the catalytic activity for the antioxidant enzyme copper-zinc superoxide dismutase ( $\mathrm{Cu}, \mathrm{Zn}, \mathrm{SOD})$, while zinc plays a critical structural role [52].

According to the correlation coefficient results, $\mathrm{N}$ is negatively correlated with $\mathrm{P}, \mathrm{Na}$, and $\mathrm{Ca}$, whereas $\mathrm{P}$ is negatively correlated with $\mathrm{Ca}$ and $\mathrm{Mg}$, but in case of $\mathrm{Mn}$, it showed significant correlation $(P<0.05)$. K was negatively correlated with $\mathrm{Ca}$ and $\mathrm{Mg}$, but $\mathrm{Na}$ showed significant negative correlation $(P<0.05)$ with $\mathrm{Mg}$. Ca was negatively correlated with $\mathrm{Zn}$ and $\mathrm{Mn}$, whereas $\mathrm{Mg}$ was also negatively correlated with $\mathrm{Zn}, \mathrm{Fe}$, and $\mathrm{Mn}$. On the other hand $\mathrm{Zn}$ showed significant $(P<0.05)$ correlation with Fe, and Fe showed significant correlation with $\mathrm{Mn}$ at $0.05 \%$ level (Table 6).

\section{Conclusions}

In general, this study demonstrated that different purslane accessions had significantly different bioactive compound content and revealed different levels of responses to biological activity tests. From the overall finding it is found that ornamental purslane has higher TPC (V8), higher TFC (V10), and higher TCC (V4) and antioxidant activities than the common purslane (V12 and V13). Regarding mineral constituents, the common purslane has more mineral composition than ornamental ones. So, we suggest that, both types of purslane are safe for human consumption and very good vegetable food crops for natural minerals, antioxidants, and medicinal purposes.

\section{Conflict of Interests}

The authors declare that there is no conflict of interests regarding the publication of this paper.

\section{Acknowledgments}

The authors sincerely acknowledge the UPM Research University Grant (01-02-12-1695RU) for financial support of the project and International Graduate Research Fellowship (IGRF) for Ph.D. Fellowship.

\section{References}

[1] M. Coquillat, Bulletin Mensuel de la Société Linnéenne de Lyon, vol. 21, 1951.

[2] A. C. Dweck, "Purslane-Portulaca oleracea: the global panacea," 2001, http://www.dweckdata.com/Published_papers/Portulaca_oleracea.pdf.
[3] J. Samy, M. Sugumaran, and K. L. W. Lee, Herbs of Malaysia: An Introduction to the Medicinal, Culinary, Aromatic and Cosmetic Use of Herbs, Times, Kuala Lumpur, Malaysia, 2004.

[4] Y. F. Chu, J. Sun, X. Wu, and R. H. Liu, "Antioxidant and antiproliferative activities of common vegetables," Journal of Agricultural and Food Chemistry, vol. 50, no. 23, pp. 6910-6916, 2002.

[5] L. W. Mitich, "Common purslane (Portulaca oleracea)," Weed Technology, vol. 11, no. 2, pp. 394-397, 1997.

[6] J. S. Mossa, M. A. Al-Yahya, and I. A. Al-Meshal, Medicinal Plants of Saudi Arabia, vol. 1, King Saud University Press, Riyadh, Saudi Arabia, 1987.

[7] N. Feinbrun-Dothan and A. Darin, "Portulacaceae," in Analytical Flora of Eretz-Israel, pp. 123-124, CANA Publishing House Ltd., Jerusalem, Israel, 1991.

[8] N. Garti, Y. Slavin, and A. Aserin, "Competitive adsorption in $\mathrm{O} / \mathrm{W}$ emulsions stabilized by the new Portulaca oleracea hydrocolloid and nonionic emulsifiers nonionic emulsifiers," Food Hydrocolloids, vol. 13, no. 2, pp. 139-144, 1991.

[9] A. P. Simopoulos, "Horticulture and human health," in Contribution of Fruits and Vegetables, B. Quebedeaux and F. Bliss, Eds., Prentice-Hall, Englewood Cliffs, NJ, USA, 1987.

[10] T. R. Omara-Alwala, T. Mebrahtu, D. E. Prior, and M. O. Ezekwe, "Omega-three fatty acids in purslane (Portulaca oleracea) tissues," Journal of the American Oil Chemists' Society, vol. 68, no. 3, pp. 198-199, 1991.

[11] A. P. Simopoulos, H. A. Norman, J. E. Gillaspy, and J. A. Duke, "Common purslane: a source of omega- 3 fatty acids and antioxidants," Journal of the American College of Nutrition, vol. 11, no. 4, pp. 374-382, 1992.

[12] A. P. Simopoulos, "Omega-3 fatty acids in health and disease and in growth and development," The American Journal of Clinical Nutrition, vol. 54, no. 3, pp. 438-463, 1991.

[13] M. A. Weiner, "Cholesterol in foods rich in omega-3 fatty acids," The New England Journal of Medicine, vol. 315, no. 13, article 833, 1986.

[14] M. Alothman, R. Bhat, and A. A. Karim, "Antioxidant capacity and phenolic content of selected tropical fruits from Malaysia, extracted with different solvents," Food Chemistry, vol. 115, no. 3, pp. 785-788, 2009.

[15] A. Crozier, M. E. J. Lean, M. S. McDonald, and C. Black, "Quantitative analysis of the flavonoid content of commercial tomatoes, onions, lettuce, and celery," Journal of Agricultural and Food Chemistry, vol. 45, no. 3, pp. 590-595, 1997.

[16] V. L. Singleton, R. Orthofer, and R. M. Lamuela-Raventós, "Analysis of total phenols and other oxidation substrates and antioxidants by means of folin-ciocalteu reagent," Methods in Enzymology, vol. 299, pp. 152-178, 1998.

[17] M. F. Abu Bakar, M. Mohamed, A. Rahmat, and J. Fry, "Phytochemicals and antioxidant activity of different parts of bambangan (Mangifera pajang) and tarap (Artocarpus odoratissimus)," Food Chemistry, vol. 113, no. 2, pp. 479-483, 2009.

[18] H. E. Khoo, A. Ismail, N. Mohd-Esa, and S. Idris, "Carotenoid content of underutilized tropical fruits," Plant Foods for Human Nutrition, vol. 63, no. 4, pp. 170-175, 2008.

[19] W. Brand-Williams, M. E. Cuvelier, and C. Berset, "Use of a free radical method to evaluate antioxidant activity," Food Science and Technology, vol. 28, no. 1, pp. 25-30, 1995.

[20] I. F. F. Benzie and J. J. Strain, "The ferric reducing ability of plasma (FRAP) as a measure of "antioxidant power": the FRAP assay," Analytical Biochemistry, vol. 239, no. 1, pp. 70-76, 1996. 
[21] T. S. Ma and G. Zuazaga, "Micro-kjeldahl determination of nitrogen. A new indicator and an improved rapid method," Industrial and Engineering Chemistry, vol. 14, no. 3, pp. 280-282, 1942.

[22] SAS, The SAS System for Windows, Version 9.2 (TS1M0), SAS Institute Inc., Cary, NC, USA, 2013.

[23] B. B. Li, B. Smith, and M. M. Hossain, "Extraction of phenolics from citrus peels, I: solvent extraction method," Separation and Purification Technology, vol. 48, no. 2, pp. 182-188, 2006.

[24] A. Othman, A. Ismail, N. Abdul Ghani, and I. Adenan, "Antioxidant capacity and phenolic content of cocoa beans," Food Chemistry, vol. 100, no. 4, pp. 1523-1530, 2007.

[25] C. A. Manach, A. Scalbert, C. C. Morand, C. Rémésy, and L. Jiménez, "Polyphenols: food sources and bioavailability," The American Journal of Clinical Nutrition, vol. 79, no. 5, pp. 727747, 2004.

[26] C. A. Rice-Evans, N. J. Miller, and G. Paganga, "Structureantioxidant activity relationships of flavonoids and phenolic acids," Free Radical Biology and Medicine, vol. 20, no. 7, pp. 933956, 1996.

[27] M. López-Vélez, F. Martínez-Martínez, and C. del Valle-Ribes, "The study of phenolic compounds as natural antioxidants in wine," Critical Reviews in Food Science and Nutrition, vol. 43, no. 3, pp. 233-244, 2003.

[28] A. V. Rao and L. G. Rao, "Carotenoids and human health," Pharmacological Research, vol. 55, no. 3, pp. 207-216, 2007.

[29] S. Voutilainen, T. Nurmi, J. Mursu, and T. H. Rissanen, "Carotenoids and cardiovascular health," The American Journal of Clinical Nutrition, vol. 83, no. 6, pp. 1265-1271, 2006.

[30] E. J. Johnson, “The role of carotenoids in human health," Nutrition in Clinical Care, vol. 5, no. 2, pp. 47-49, 2002.

[31] S. Agarwal and A. V. Rao, "Carotenoids and chronic diseases," Drug Metabolism and Drug Interactions, vol. 17, no. 1-4, pp. 189210, 2000.

[32] R. Elliott, "Mechanisms of genomic and non-genomic actions of carotenoids," Biochimica et Biophysica Acta, vol. 1740, no. 2, pp. 147-154, 2005.

[33] S. A. R. Paiva and R. M. Russell, “ $\beta$-carotene and other carotenoids as antioxidants," Journal of the American College of Nutrition, vol. 18, no. 5, pp. 426-433, 1999.

[34] P. Astorg, "Food carotenoids and cancer prevention: an overview of current research," Trends in Food Science and Technology, vol. 8, no. 12, pp. 406-413, 1997.

[35] C. Jewell and N. M. O’Brien, "Effect of dietary supplementation with carotenoids on xenobiotic metabolizing enzymes in the liver, lung, kidney and small intestine of the rat," British Journal of Nutrition, vol. 81, no. 3, pp. 235-242, 1999.

[36] J. S. Bertram, "Carotenoids and gene regulation," Nutrition Reviews, vol. 57, no. 6, pp. 182-191, 1999.

[37] M. K. Uddin, A. S. Juraimi, M. E. Ali, and M. R. Ismail, "Evaluation of antioxidant properties and mineral composition of purslane (Portulaca oleracea L.) at different growth stages," International Journal of Molecular Sciences, vol. 13, pp. 1025710267, 2012.

[38] Y. Y. Lim and E. P. L. Quah, "Antioxidant properties of different cultivars of Portulaca oleracea," Food Chemistry, vol. 103, no. 3, pp. 734-740, 2007.

[39] S. Siriamornpun and M. Suttajit, "Microchemical components and antioxidant activity of different morphological parts of thai wild purslane (Portulaca oleracea)," Weed Science, vol. 58, no. 3, pp. 182-188, 2010.
[40] D. Prakash and M. Pal, "Nutritional and antinutritional composition of vegetable and grain amaranth leaves," Journal of the Science of Food and Agriculture, vol. 57, pp. 573-583, 1991.

[41] F. O. Jimoh and A. T. Oladiji, "Preliminary studies on Piliostigma thonningii seeds: proximate analysis, mineral composition and phytochemical screening," African Journal of Biotechnology, vol. 4, no. 12, pp. 1439-1442, 2005.

[42] J. Hussain, N. R. Rehman, A. L. Khan et al., "Determination of macro and micronutrients and nutritional prospects of six vegetable species of Mardan," Pakistan Journal of Botany, vol. 43, no. 6, pp. 2829-2833, 2011.

[43] J. A. Bangash, M. Arif, F. Khan, F. Khan, Amin-Ur-Rahman, and I. Hussain, "Proximate composition, minerals and vitamins content of selected vegetables grown in Peshawar," Journal of the Chemical Society of Pakistan, vol. 33, no. 1, pp. 118-122, 2011.

[44] F. C. Luft, Present Knowledge in Nutrition, chapter 26, Nutrition Foundation, Washington, DC, USA, 1990.

[45] B. E. Miller and A. W. Norman, "Hand Book of Vitamins," Dekker, New York, NY, USA, 1984.

[46] M. E. Shils, "Magnesium," in Handbook of Nutritionally Essential Minerals, B. L. O’Dell and R. A. Sunde, Eds., Marcel Dekker, New York, NY, USA, 1998.

[47] J. L. Beard and H. D. Dawson, "Iron," in Handbook of Nutritionally Essential Minerals, B. L. O'Dell and R. A. Sunde, Eds., Marcel Dekker, New York, NY, USA, 1997.

[48] V. F. Fairbanks, "Iron in medicine and nutrition," in Nutrition in Health and Disease, M. Shils, J. A. Olson, M. Shike, and A. C. Ross, Eds., Williams and Wilkins, Baltimore, Md, USA, 9th edition, 1999.

[49] M. C. Linder and M. Hazegh-Azam, "Copper biochemistry and molecular biology," The American Journal of Clinical Nutrition, vol. 63, no. 5, pp. 797-811, 1996.

[50] B. L. O'Dell, "Role of zinc in plasma membrane function," Journal of Nutrition, vol. 130, no. 5, pp. 1432-1436, 2000.

[51] F. H. Nielsen, "Ultra trace minerals," in Nutrition in Health and Disease, M. Shils, J. A. Olson, M. Shike, and A. C. Ross, Eds., Williams and Wilkins, Baltimore, Md, USA, 9th edition, 1999.

[52] Food and Nutrition Board, Institute of Medicine, Dietary Reference Intakes for Vitamin A, Vitamin K, Boron, Chromium, Copper, Iodine, Iron, Manganese, Molybdenum, Nickel, Silicon, Vanadium, and Zinc, National Academy Press, Washington, DC, USA, 2001. 

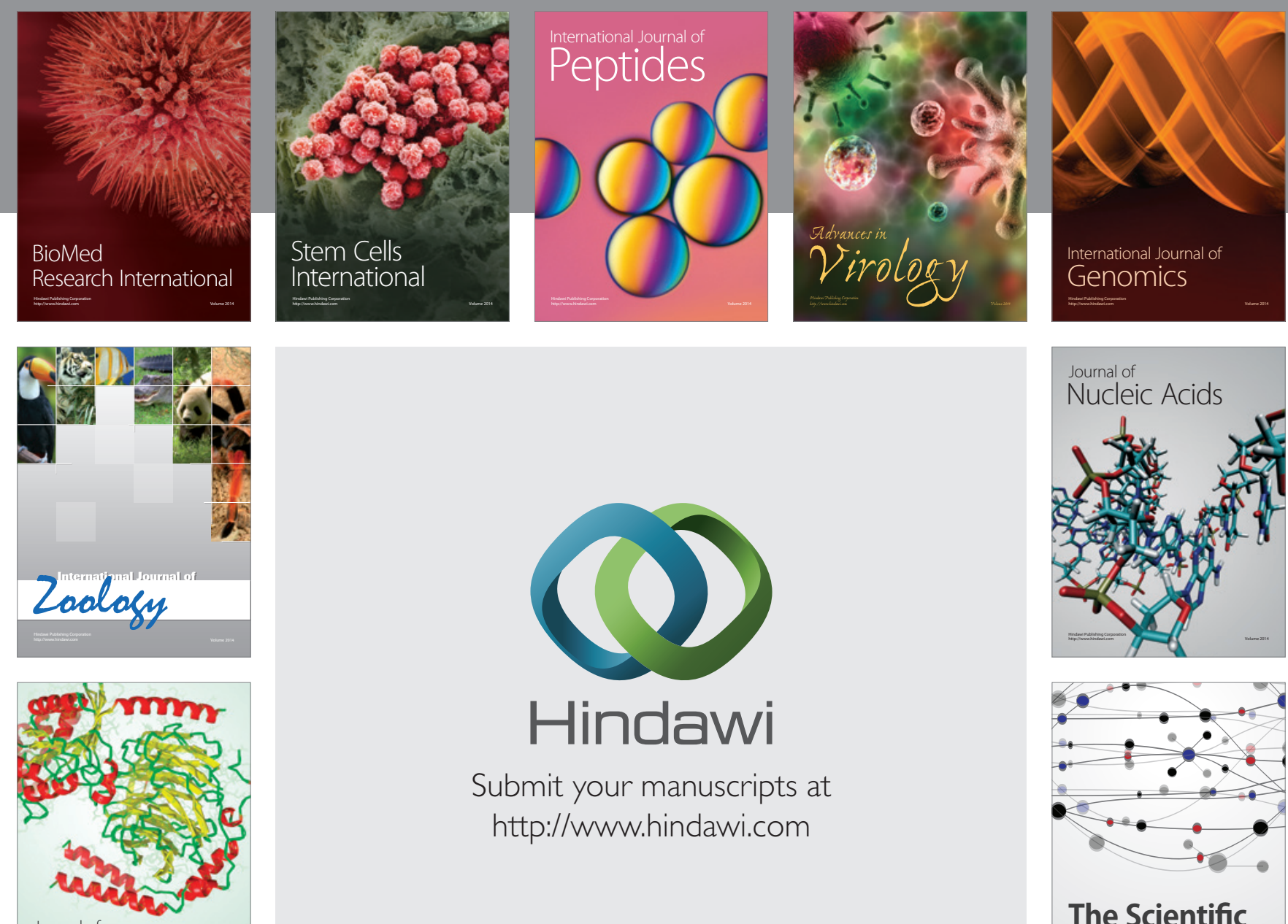

Submit your manuscripts at

http://www.hindawi.com

Journal of
Signal Transduction
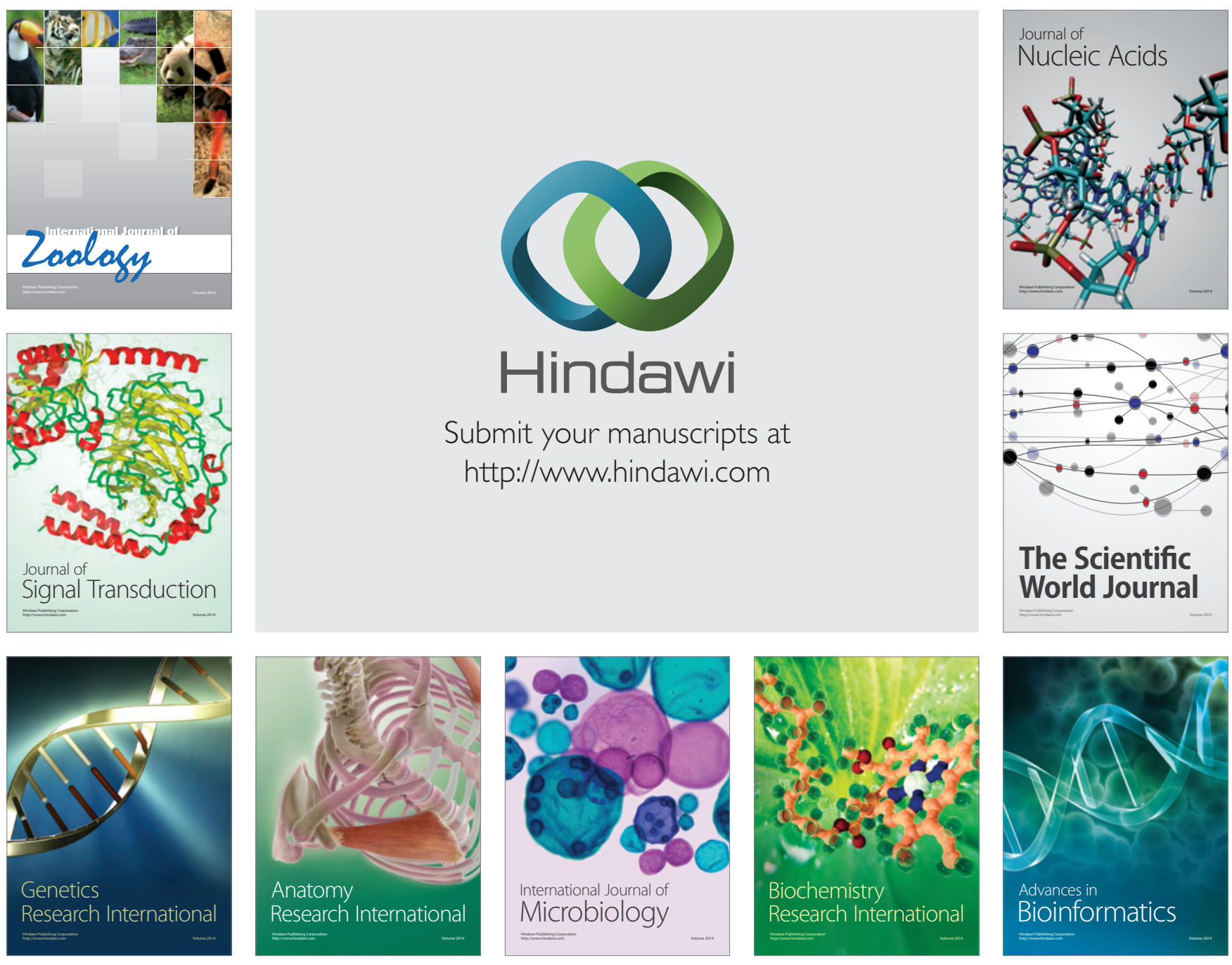

The Scientific World Journal
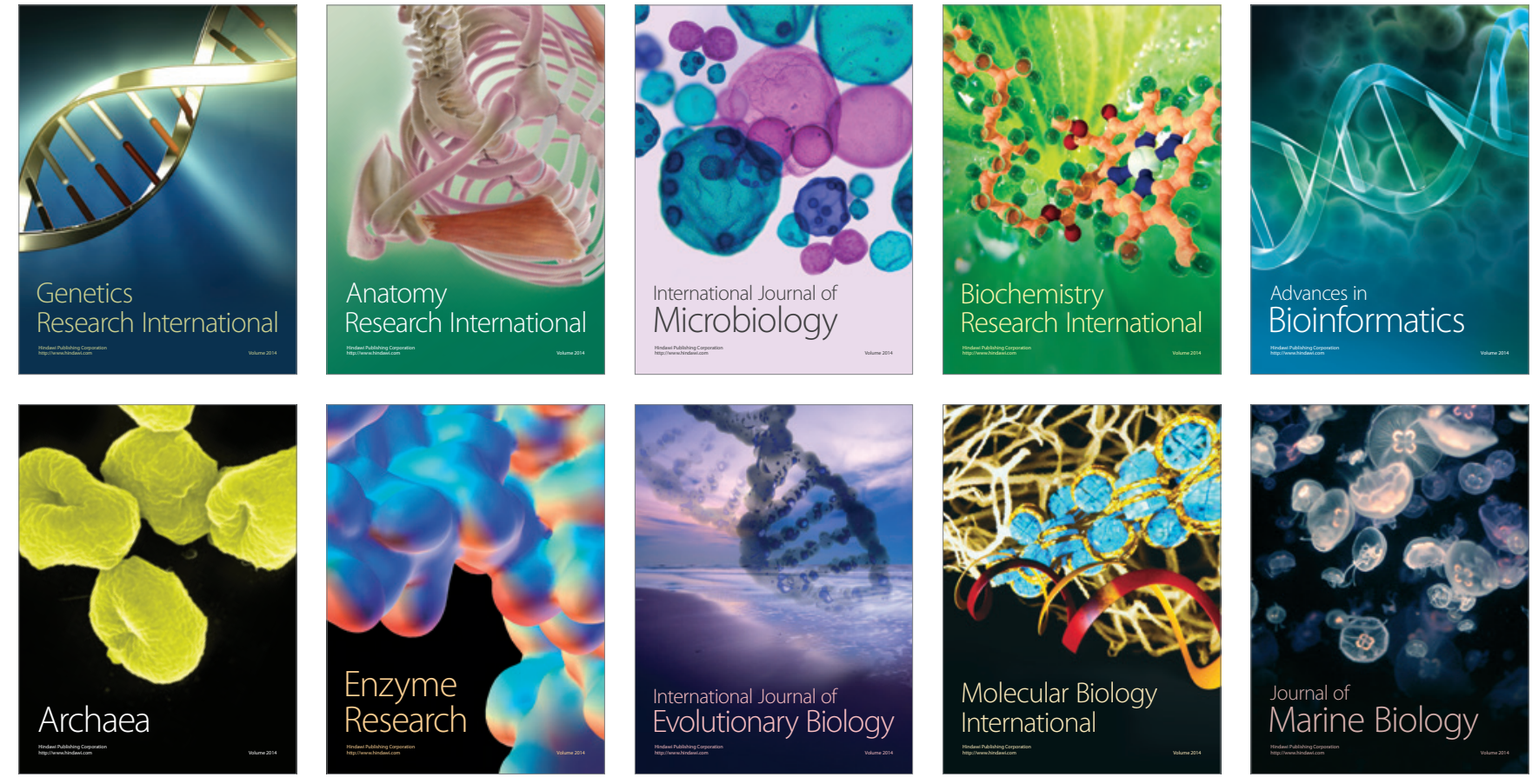